\title{
A TEXTUAL ANALYSIS OF DAVIDSOCOMEDY'S UGLY GIRLS YOUTUBE RESPONSE VIDEO
}

\section{LIVIA POLJAK}

Simon Fraser University

\begin{abstract}
Using positioning theory and Bourdieu's theories on speaker legitimacy, this article explores the link between identity and speech in the context of a YouTube video entitled Vlog 29: Ugly Girls by DavidSoComedy. By positioning himself as a legitimate speaker of African American Vernacular English (AAVE), Korean-American YouTuber DavidSoComedy effectively changes this form of English from an ethnic identity marker to a social identity marker. The article thus continues in the tradition of more recent researchers that have suggested that identity, and the languages associated with that identity, are fluid and ever-changing, rather than fixed.
\end{abstract}

Keywords: language and identity, identity markers, accent and identity, speaker legitimacy 


\section{Introduction: Why this Text?}

In an era where outright racism is harshly discouraged, and even illegal, discrediting the way one speaks - either because of a foreign accent, or local dialect - has endured in our society. This is particularly true in the case of minority groups facing discrimination and marginalization, perhaps because language discrimination is difficult to link to racism (Wolfram \& Shilling-Estes, 2006; Munro, 2003; Purnell et al., 1999; Lippi-Green, 1997a, 1997b). Nevertheless, it is a rarely disputed that language, together with its most salient features, such as accent, lexis and grammar, are often associated with one's own identity, and indeed group identity (ex: Gumperz, 1982; Giles \& Johnson, 1987; Gatbonton et al., 2005; Kramsch, 2006; Gasquet-Cyrus et al., 2012).

Language can be malleable and changeable (Norton, 1995; Pavlenko, 2002; Norton \& Toohey, 2011). It exposes you for you are, or who you want to be. Yet linguistic features, as heard in such variations as African American Vernacular English (AAVE), can at times be so strongly associated with one group, that they can give the impression that language is fixed (see previous research on language and identity Kramsch, 2006; Block, 2007). I too am to stranger to such beliefs, despite knowing the contrary: Some years ago, while watching YouTube, I came across a comedy channel that truly embodies the link between language and social identity. The YouTube clip in question, by comedian DavidSoComedy, uses a seemingly stylized AAVE accent in answer to a rant video posted by PinkCashSwag (who is, herself, a speaker of AAVE). Upon observing the YouTube video, I began to ask why an accent that is typically associated with African American speech is being employed by someone who is neither African American, nor would likely identify as such. By analysing this text, I hope to begin exploring what role accents play in self and group affiliation. I begin this short analysis with a brief background on the comedian David So and his comedy channel's main set-up. Using transcriptions from the YouTube video and comments from the viewers as evidence, I will use positioning theory as well as Bourdieu's concept of the legitimate speaker to briefly demonstrate how the YouTube channel DavidSoComedy positions the self, as a Korean-American growing up in an American ghetto, within the framework of whiteness/blackness in the sketch entitled Vlog 29: Ugly Girls. The analysis will focus on two key features of the vlog post: comments on PinkCashSwag's mastery of English, and comments made on the state of her hair.

\section{Premise}

As mentioned, the YouTube video in question was made in response to a 2012 video post uploaded by PinkCashSwag (whose original video and channel has since been removed). The response - sometimes called "rant" if the presenter behaves in an angry and impassioned manner - was made by a YouTube comedian named David So. According to his fan page, David So was born in Korea but moved with his family to California at age 2 where he currently resides. Since starting his channel in 2011, David So has amassed about 1.4 million subscribers on his personal channel, DavidSoComedy (DSC), on YouTube, and has recently starred in Justin Chon's film Gook. David So is just one of a number of highly successful Asian-American YouTubers (see also Michelle Phan (8.9 million subscribers), Timothy DeLaGhetto (1.1 million subscribers), 
Kevin $\mathrm{Wu}$ (2.8 million subscribers), Ryan Higa (21.2 million subscribers) and Freddie Wong (8.2 million subscribers)), all of whose popularity, according to Chun (2013), could potentially be attributed to a growing awareness of Asian figures (particularly Asian men) in today's pop culture (through K-Pop, J-Pop, Korean dramas etc).

As is the case with most YouTube channels, DSC's rant/response sketches follow a basic formula: introduction of original post (OP), followed by mocking/comedic comments on OP and finally some closing statements reflecting David So's moral understanding of OP - all this totally between 3-4 minutes. This three-part video monologue is also observed in Vlog \#29: Ugly Girls, where there is a brief explanation about the OP, with selected inserts of the clip spaced throughout the response video. Here, we the viewers, are shown what PinkCashSwag's original Ugly Girls video (which will be known from now on as "Original Rant Video" or ORV for short) looked like: we are shown a young, high school aged girl who, in the words of DSC, "rants about ugly people" using colloquial language often associated with AAVE. Each of the ORV's arguments are broken down to what DSC deems to be the most salient points in need of ridicule and criticism. Finally, the skit ends with a moral (ex: "it's not about the way you look, it's about the way you carry yourself').

The two major themes that DSC chooses to comment on are related to the ORV's hair and intellect, therefore, these are the points that I chose to transcribe and subsequently analyse. Because the primary aim here is to present DSC's speech style as faithfully as possible, the transcription style I chose is as follows:

- No punctuation

- No capitals

- Use of ellipsis to indicate longer pauses

- Use of slash to indicate jump from one point to another (in the place of a period/comma)

- Elimination of ending sounds (-ing = in/you vs your etc.)

- Use of brakes () to indicate uncertainty

- Unsure of a word/sound

- Use of underscore _ for linking

- Use of asterisk for bleeped sounds

- Use of Bold under transcription for written text in video

- Use of italics to indicate hand motions

- Breaks and time recorded for all jump-cuts

\section{Analysis 1: Language}

Because this analysis will look at the use of AAVE, I wanted the transcription to reflect spoken speech as opposed to written speech (hence the lack of punctuation etc.). This type of transcription also made it easier to pin-point the way in which certain words are pronounced. An example of this is my choice to not write -ing endings or to drop the -r in words like "your" in some places and not in others, all depending on what can be heard and what cannot be heard in the video. This way, I was able to go back and to reread the text in order to assess the 
consistency of DSC's vernacular English. Indeed, there are a number of reasons why David So would have chosen to use a stylized vernacular English in answer to the OVR.

Throughout the video, DavidSoComedy (DSC) appears to use African American Vernacular English (AAVE). As this language style is key to our understanding of both DSC's message and YouTuber persona, I begin this next part with an analysis on the employment of AAVE in DSC video:

DSC: DavidSoComedy

OVR: Original Video Rant (PinkCashSwagg)

Minutes 0:59-1:17:

0:59

OVR: what the fuck*..... do yall think yall are... y'all ugly bitches be ready to fuck* with everybody CLAP CLAP CLAP

1:07

DSC: heres anotha thing/ you(r) ghetto/ and im not talkin about that ghetto like ahhh bitch you ghetto

\section{HAND WAVE}

$1: 12$

DSC: no ya ass is fuckin* ghetto

1:13

DSC: you know how i know your ghetto when every time you tryna make a point you gotta clap ya hands

1:17

DSC: lookin like a retarded seal

$$
\text { CLAP--------- }
$$

Minutes 2:04-2:15:

2:04

DSC: i have neva seen hair follicles that angry in ma life/ looks like a rottweiler's been chewing on your hair all day

2:09

DSC: how are you gonna be talkin about beein educated when you (got?) the vernacula of a hood ra(t) on turrets

2:14

DSC: lookin like the only alphabet_you know is in a damn soup

2:15

DSC: bitch that not even a hood accent youve got/tha(t)s a speech impedimen(t) 
At first, when observing the above transcription, it appears that he may simply be mocking the girl and using AAVE as a way to index her as the "other". However, as the video comes to a close, he continues to use forms of AAVE as the video's message takes a more serious turn. In fact, as a fan of DSC and having seen several of his videos previously, I knew from the beginning that, while AAVE may not be the only English variety he was familiar with, its use in his videos is not merely an act. Upon viewing other "rant" videos in response to, for example, European-Americans (see Vlog \#4: Asians in the Library-UCLA Girl (Amanda Wallace) Going Wild on Asians) he still continues to use AAVE to express his thoughts. This is perhaps because, within the storyline of 'non-white America', David So is positioning himself as a legitimate speaker, and in fact a part of, the 'group' with all others who speak AAVE. This may be because of his upbringing. As was mentioned earlier, David So has stated that he grew up in a black neighborhood where his family owned a black beauty supply store that sold wigs and weaves to a primarily African American female cliental. Being surrounded by people who spoke AAVE might have given the comedian the tools to build what Lippi-Green (1997) refers to as a 'sound house', or in David So's case, multiple sound houses. His ability to switch from standard American English, to AAVE and even to a stylized Asian-American speech, makes it clear that David So is 'tri'-dialectal. In an article by Chun (2001), the use of both AAVE within an MAE (Mainstream American English) frame by a Korean American university student was explained as a way of indexing both whiteness and blackness in order to "project a uniquely Korean American male identity in the context of complex historical, cultural, and political relationships that Korean American men have with both African Americans and European Americans". Like David So, this student (Jin) claimed to have learned to use elements of AAVE because he grew up in "the ghetto". In the case of David So however, we can go beyond viewing the use of AAVE as a means of highlighting a unique Korean-American identity. In fact, it can be argued that David So's use of AAVE is not an attempt at being 'black', or 'KoreanAmerican'. Rather, it can be seen as his own positioning within the "ghetto" storyline, leading to a widening of the definition of what it means to be a member of the ghetto. Rather than it being a black/white divide, the 'ghetto' can be thought of as a socio-economic divide in which any one from any race can take up residence, provided they have a lower economic status. David So is essentially, to borrow from Rampton $(1995,2009)$ 'crossing' linguistic and ethnic boundaries in order to create new ones, in order to better represent his identity, or his 'reality'. It can be assumed that to David So, being 'from the ghetto' extends beyond race or ethnicity, which, in light of recent political events, is often overlooked. For example, Trump's use of 'ghetto' during his presidential campaigning as a means of describing poor, black communities (Diamond, 2016), showcases how the term is often treated as a 'Black only' issue, and positions African Americans as the perpetual 'other' in comparison to European-Americans, or other so-called 'model minorities' (Chun, 2001) such as Asian-Americans. David So's agentive positioning within the American 'ghetto' storyline arguably expands and even modifies this existing storyline, to a certain extent, making it much more inclusive than before. By using YouTube as a 
platform for his positioning, he is able to reach a much wider audience, making the matter of the 'legitimate ghetto speaker' a public talking point.

However, for David So's use of AAVE to be deemed legitimate, this audience, (i.e.: those watching his videos) would need to be receptive to his use of this particular English variant. As Bourdieu (1977) states, "One does not speak to any Tom, Dick or Harry; any Tom, Dick or Harry does not take the floor. Speech presupposes a legitimate transmitter addressing a legitimate receiver, one who is recognized and recognizing" (p. 649). In other words, if he is not accepted as a legitimate speaker of AAVE, DSC's use of this vernacular might take a racial and possibly racist turn in the eyes of the audience. Indeed, audience support is highly important, as was demonstrated by Alim et al. (2010) when entering the arena of the, otherwise perceived, 'other'. As it happens, DSC's audience is, more often than not, accepting and understanding of his use of AAVE in his videos. Table 1. below, illustrates three of the most common categories of comments:

\begin{tabular}{|c|c|}
\hline COMMENT TYPE & EXAMPLE (TOTAL OF 13) \\
\hline "Rejecting" Comments & $\begin{array}{l}\text { VineFever } 4 \text { years ago } \\
\text { Racist fat ass chinaman say that ghetto shit } \\
\text { to a real nigga get yo big ass knocked out } \\
\text { bitch } \\
\text { fjiowheiofjef } 4 \text { years ago } \\
\text { Your half asian half back accent really } \\
\text { ticks me off. } \\
\text { Fleeky Brow } 4 \text { years ago } \\
\text { As a Black male, I talk like any other } \\
\text { human being, thank you. Determining } \\
\text { English communication based off skin } \\
\text { color is a really ignorant thing to do... }\end{array}$ \\
\hline "Accepting Comments & $\begin{array}{l}\text { The Senate } 4 \text { years ago } \\
\text { He is putting her in her place, teaching her a } \\
\text { lesson. Are you defending her? Nigga, you be } \\
\text { crazy. } \\
\text { ivybuu } 14 \text { years ago } \\
\text { He grew up in the ghetto. } \\
\text { Dejah Turner } 4 \text { years ago } \\
\text { "Because you and your hair should take the } \\
\text { same advice. And relax" }\end{array}$ \\
\hline
\end{tabular}




\begin{tabular}{|c|c|}
\hline & 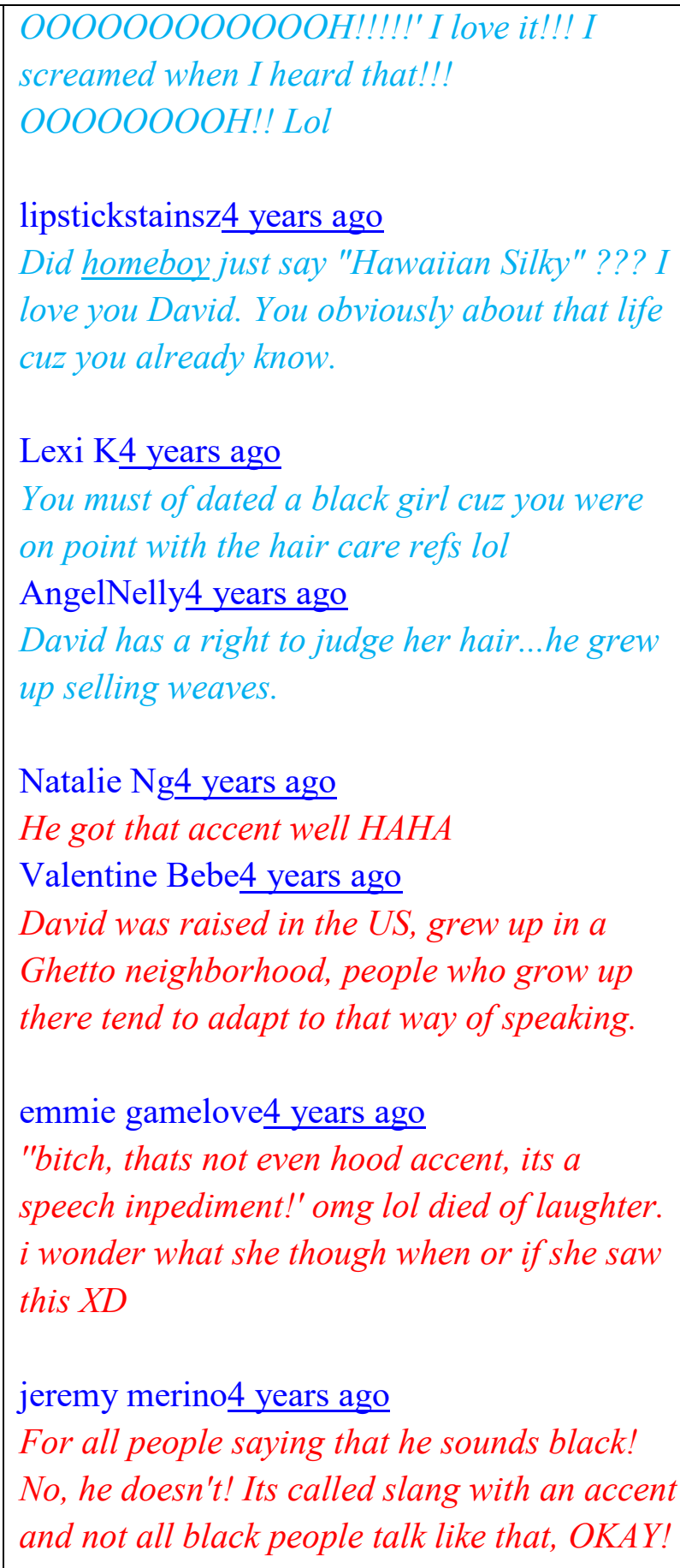 \\
\hline Neutral Comments/Comments about ORV & $\begin{array}{l}\text { James } \mathrm{O} \underline{4} \text { years ago } \\
\text { Black talk } \\
\text { SapphireShield } \underline{4 \text { years ago }} \\
\text { I believe so. It's a way of speaking that some } \\
\text { sad humans adopt called 'ghetto'. }\end{array}$ \\
\hline
\end{tabular}




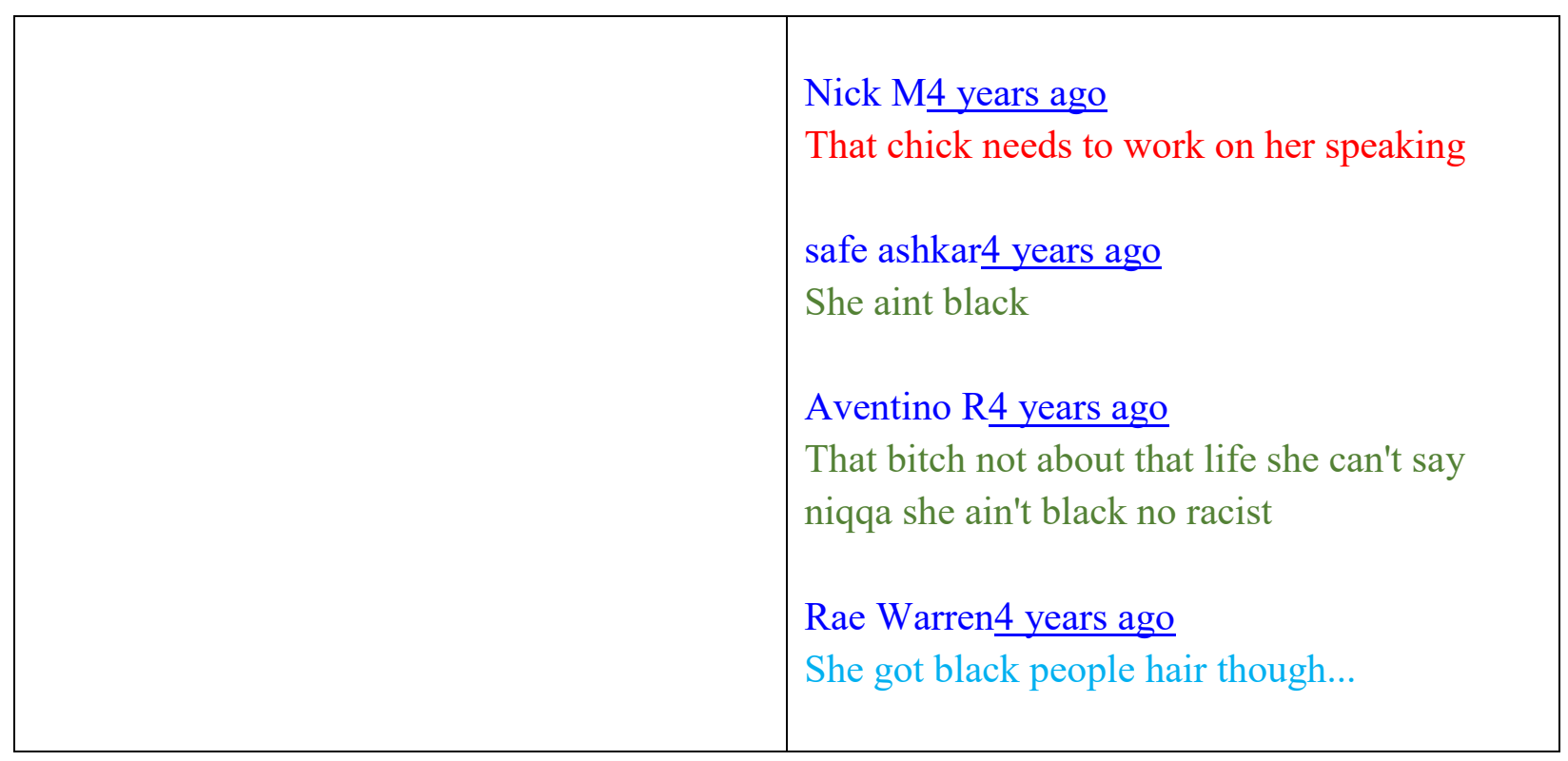

Upon observing the comments made during the year his YouTube clip was released, out of the 13 comments specifically associated with group affiliation, 10 comments were found to be receptive of DSC while only 3 rejected his position as 'part of the group'. One commenter went so far as to characterize DSC's speech as "half Asian half Black" even though objectively, no Asian accent can be detected. Such an assertion may come from the fact that David So himself has Asian features, and previous studies have demonstrated that, when presented with an Asian visage together was a recorded speech, it was enough for listeners to imagine hearing a foreign accent even when there wasn't one (Rubin, 1992).

The positive comments tended to praise and specifically reiterate David So's access to the 'in-group'. For example, as seen above, comments that point out David So's upbringing in 'the ghetto', his knowledge of hair products like Hawaiian Silk and Motions, being addressed as 'home boy' by one supposedly African American commenter, and referring to his way of speaking as 'ghetto' rather than AAVE, present David So as a legitimate group member, and thus, a legitimate speaker. It should, however, be noted that his position in the group does appear to, at times, be precarious at best. Goodwin \& Alim (2010) demonstrated how a white workingclass school girl was able to maintain her position in a primarily upper-middle class group of elementary school girls only by constantly positioning another black, working-class girl (considered "twice removed from the centre" due to her race and socio-economic background) as a 'tag-along girl'. Similarly, David So's place is safe so long as the OVR's position as 'Black' is either contested (ex: That bitch not about that life she can't say niqqa [SIC] she ain't black no racist/ She aint [SIC] black), or her points of view in the community are contested (ex: He is putting her in her place, teaching her a lesson. Are you defending her? Nigga, [SIC] you be crazy). 


\section{Analysis 2: Hair and the African American community}

As long as DSC continues to be seen as a member of the 'ghetto community' and continues to make socially appropriate references - as he does with hair - this video will remain acceptable to his audience. However, by emphasising his position as 'insider' in the black ghetto community, David So still perpetuates harmful stereotypes about African American women, with his constant derogatory references to the state of the OVR's hair. In the African American community, hair is a particular 'sore point', and David So's constant references to typically Black hair-straightening products paint a larger picture of what is socially considered as 'good' hair. In this case 'good' would be whatever hair texture is the closest to 'white people's hair' while 'bad' would be anything that is "short, matted, kinky, nappy, coarse, brittle, and wooly" [SIC] (Lester, 2000). These hair classifications are very deeply imbedded in the history of slavery in the United States, where having lighter skin and 'good' hair would be associated with house slaves (seen as somewhat more privileged), whereas having darker coloured skin and 'bad' hair would mean being relegated to working in the fields (Lester, 2000). Today's arguments surrounding 'black hair' and beauty standards are parts of a much larger standpoint that pits Afrocentrism against Eurocentrism in the United States. Patton (2006) comments that on the one hand, "Hair straightening was a way to challenge the predominant nineteenth-century belief that black beauty was ugly" while on the other hand, this practice is perceived as controversial as it could be a sign of self-loathing and an attempt to emulate 'white' standards of beauty. Essentially, hair straightening can be considered a form of self-colonization. In fact, David So spends nearly half of his video making specific references to the OVR's hair, stating she has "angry hair follicles", appears as though a "Rottweiler's been chewing on your head all day" or has "Chewbacca-ass hair". Even the very last comment DSC makes in the video, suggesting the OVR should 'relax' (referring to hair straightening), is presented almost as an afterthought, as though it is a given norm for black women to have to straighten their hair for beauty purposes in American society in order to be seen as clean or socially acceptable. Furthermore, the shear amount of time allocated to the OVR's hair in a video about 'ugly people' further anchors the point that her hair, and indeed all 'natural' black hair is also 'ugly'. David So's hair commentary is deeply problematic not only because it merely reinforces the status quo about black beauty, but also because those who are themselves part of the 'in-group' share this way of thinking and tend to perpetuate the same harmful stereotypes wrought against their own community (as was clearly demonstrated in many of the comments seen in Table 1). This demonstrates the power of indexed 'whiteness' within minority communities. It is also this same social 'whiteness' that we observe in Alim et al. (2013) with regards to their analysis on interracial rap battles and Chun's (2013) analysis on YouTuber KevJumba's attempt at 'acting black' around his African American friends. It is through 'whiteness' and 'white beauty standards' that we come to understand the OVR as being ugly herself, rather than through DSC's comments alone. 


\section{Concluding Thoughts and Future Research}

DavidSoComedy's YouTube video response represents both a break from traditional perceptions of who is a legitimate member of the 'ghetto', as well as an affirmation of certain Black stereotypes found throughout US society. When observed through a much wider lens, this juxtaposition of new and old storylines allows the discourse on accents, dialects and identity to be ever fluid and every changing. This brief textual analysis focused first on language and identity, and then transitioned into a discussion on the perpetuation of negative social stereotypes. Today, in the age of social media where representations of the self are more and more public, questions of in-group and out-group affiliation (see Tajfel and Turner, 1978) may become more divisive and exclusionary. In the case of this comedy video, David So may have further perpetuated harmful stereotypes in showing his 'rightful' place as a group member of the 'ghetto' community. Yet he may also have demonstrated that the term 'ghetto' can go beyond one single ethnicity. Ultimately, as it was observed in DavidSoComedy's rant video, the right to feel comfortable in one's own linguistic skin(s) is the basis of the discourse on the legitimate speaker and will likely remain so until the moment a particular position changes the direction of the whole story. Until that time, we can but produce and reproduce.

See $h t t p s: / / w w w . y o u t u b e . c o m / w a t c h ? v=$ gealj6uvmC4\&t=1s for full video. 


\section{References}

Alim, H. S., Lee, J., \& Carris, L. M. (2010). Short fried-rice-eating Chinese MCs" and "goodhair-havin uncle Tom Niggas": Performing race and ethnicity in freestyle rap battles. Journal of Linguistic Anthropology, 20(1), 116-133.

Block, D. (2007). Second Language Identities (1st ed.). London: Continuum International Publishing Group.

Bourdieu, P. (1977). The economics of linguistic exchanges. Information (International Social Science Council), 16(6), 645-668.

Chun, E. (2001). The construction of White, Black, and Korean American identities through African American vernacular English. Journal of Linguistic Anthropology, 11(1), 52-64.

Chun, E. (2013). Ironic blackness as masculine cool: Asian American language and authenticity on YouTube. Applied Linguistics, 34(5), 592-612.

Diamond, J. (2016, October 27). Trump refers to "ghettos" in discussing African-American issues [News]. Retrieved from https:/www.cnn.com/2016/10/27/politics/donald-trumpghettos-african-americans/index.html

Gasquet-Cyrus, M., Trimaille, C., \& Eloy, J.-M. (2012). La discrimination à l'accent en France : idéologies, discours et pratiques. In Idéologies linguistiques et discriminations (p. $227-$ 245). Carnets d'Atelier de Sociolinguistique: L'Harmattan.

Gatbonton, E., Trofimovich, P., \& Magid, M. (2005). Learners' ethnic group affiliation and L2 pronunciation accuracy: a sociolinguistic investigation. TESOL Quarterly, 39(3), 489_ 511.

Giles, H., \& Johnson, P. (1987). The role of language in ethnic formation. In J. C. Turner \& H. Giles (Eds.), Intergroup behaviour (pp. 199-243). Oxford: Basil Blackwell.

Goodwin, M. H., \& Alim, H. S. (n.d.). "Whatever (neck roll, eye roll, teeth suck)": The situated coproduction of social categories and identities through stancetaking and transmodal stylication. Journal of Linguistic Anthropology, 20(1), 179-194.

Kramsch, C. (2006). Preview article: The multilingual subject. International Review of Applied Linguistics, 16(1), 97-110.

Lester, N. (2000). Nappy edges and goldy locks: African American daughters and the politics of hair. The lion and the unicorn, 24(2), 201-224. https://doi.org/10.1353/uni.2000.0018

Lippi-Green, R. (1997a). English with an accent: Language, ideology, and discrimination in the United States. Psychology Press.

Lippi-Green, R. (1997b). The myth of the non-accent. In English with an accent: Language, ideology, and discrimination in the United States (pp. 41-52). New York: Routledge.

Munro, M. J. (2003). A primer on accent discrimination in the Canadian context. TESL Canada Journal, 20, 73-97.

Norton, B. (1995). Social identity, investment, and language learning. TESOL Quarterly, 29(1), 9-31.

Norton, B., \& Toohey, K. (2011). Identity, language learning and social change. Cambridge University Press, 44(4), 412-446. 
Ownes Patton, T. (2006). Hey girl, am I more than my hair?: African American women and their struggles with beauty, body image, and hair. National Woman's Studies Association Journal, 18(2), 24-51.

Pavlenko, A. (2002). Poststructuralist approaches to the study of social factors in second language learning and use. In V. Cook (Ed.), Portraits of the L2 User (pp. 275-302). Clevedon: Multilingual Matters.

Prunell, T., Idsardi, W., \& Baugh, J. (1999). Perceptual and phonetic experiments on American English dialect identification. Journal of Language and Social Psychology, 18, 10-30.

Rampton, B. (1995). Crossing language and ethnicity among adolescents. New York: Longman Group Limited.

Rampton, B. (2009). Interaction ritual and not just artful performance in crossing and stylization. Language in Society, 38(2), 149-176.

Rubin, D. L. (1992). Nonlanguage factors affecting undergraduates' judgements of nonnative English teaching assistants. Research in Higher Education, 33(4), (511-531)

So. D. (DavidSoComedy). (2012, Jan, $8^{\text {th }}$ ) Vlog 29: Ugly Girls [Video File]. Retrieved from https://www.youtube.com/watch?v=gealj6uvmC4\&t=191s

Wolfram, W., \& Schilling-Estes, N. (2006). American English: Dialects and variation (2nd ed.). Malden, MA: Blackwell Pub. 